\title{
Biomechanical factors in diabetic foot disease
}

\section{PR Cavanagh*1, A Erdemir², M Petre ${ }^{3}$, TM Owings ${ }^{4}$, G Botek $^{4}$, S Chokhandre ${ }^{2}$ and R Bafna ${ }^{2}$}

\author{
Address: ${ }^{1}$ Department of Orthopaedics and Sports Medicine, University of Washington, Seattle, USA, ${ }^{2}$ Department of Biomedical Engineering, \\ Cleveland Clinic, OH, USA, ${ }^{3}$ Department of Anaesthesiology Research, Cleveland Clinic, OH, USA and ${ }^{4}$ Department of Orthopaedics, Cleveland \\ Clinic, OH, USA \\ Email: PR Cavanagh* - cavanagh@u.washington.edu \\ * Corresponding author
}

from Ist Congress of the International Foot \& Ankle Biomechanics (i-FAB) community

Bologna, Italy. 4-6 September 2008

Published: 26 September 2008

Journal of Foot and Ankle Research 2008, I(Suppl I):K4 doi:I0.I I86/I757-I I46-I-SI-K4

This abstract is available from: http://www.jfootankleres.com/content/I/SI/K4

(c) 2008 Cavanagh et al; licensee BioMed Central Ltd.

\section{Introduction}

This presentation will review the evidence that has led to the current understanding of diabetic foot complications, discuss some of the authors' current work, and identify unsolved problems for future research and clinical application.

\section{Methods}

Although the risk of vascular disease is markedly increased in diabetes [1], it is the combination of altered vascular status and nerve damage that often leads to ulceration and amputation [2]. Important early studies by Brand and colleagues [3] focused on elevated stress in a deformed, neuropathic limb as a causative factor in tissue breakdown and this has been a constant theme of experimental and analytical studies to the present day.

The stress component normal to the foot (usually called plantar pressure) has typically been available for study [4] and this quantity is associated with the risk of future ulceration [5]. We have shown it to be useful, together with foot shape, in the design of pressure relieving footwear [6] and others have derived quantities such as pressure gradient to indicate risk [7]. Recent studies of plantar shear stress [8] have reported higher neuropathic/control ratios than for plantar pressure, suggesting that shear stress may have an important role in tissue damage.
The measurement of pressure between the foot and the footwear is potentially very useful clinically [9]. If the patient is compliant with footwear use, the stresses measured using in-shoe techniques reflect the influence of anatomical structure, lower extremity function, lifestyle, and footwear construction.

Finite element modelling of the foot, and in some cases footwear, has been explored by a number of groups [1012] to provide estimates of quantities that cannot be directly measured or to perform simulations that would be onerous or dangerous for human subjects. Our own recent work has been directed towards the development of more realistic soft tissue models utilizing detailed deformation measurements of foot structures [13] and an attempt to reduce the burden of mesh development by the use of morphing techniques to modify stock meshes.

\section{Conclusion}

More effort needs to be directed towards the application of biomechanics research to benefit the patient. This will require clear demonstration of improved outcomes when biomechanically based interventions are conducted.

\section{Acknowledgements}

We acknowledge support from NIH Grants 5ROI HD037433 and T32 AR50959. 


\section{References}

I. Mazzone T, et al:: Lancet 2008, 37 I:1800-9.

2. Kles KA, Vinik Al: Curr Diabetes Rev 2006, 2(2): $131-45$

3. Bauman J, et al.: J Bone Joint Surg Am 1964, 45-B(4):652-73.

4. Bus SA, et al.: Diabetes Metab Res Re 2008:S162-80.

5. Crawford F, et al:: QJM 2007, I 00(2):65-86.

6. Owings TM, et al.: Diabetes Care 2008, 3 I (5):839-44.

7. Mueller MJ, et al.: Diabetes Care 2005, 28(I 2):2908-12.

8. Yavuz M, et al.: J Biomech 2008, 4 I (3):556-9.

9. Guldemond NA, et al.: Diabetes Res Clin Pract 2007, 77(2):203-9.

10. Cheung JT, Zhang M: Med Eng Phys 2008, 30(3):269-77.

II. Actis RL, et al.: Med Biol Eng Comput 2008, 46(4):363-7I.

12. Yarnitzky G, et al.: J Biomech 2006, 39(14):2673-89.

13. Petre M, et al.: J Biomech 2008, 4 I (2):470-4.

Publish with Biomed Central and every scientist can read your work free of charge

"BioMed Central will be the most significant development for disseminating the results of biomedical research in our lifetime. "

Sir Paul Nurse, Cancer Research UK

Your research papers will be:

- available free of charge to the entire biomedical community

- peer reviewed and published immediately upon acceptance

- cited in PubMed and archived on PubMed Central

- yours - you keep the copyright

Submit your manuscript here:

http://www.biomedcentral.com/info/publishing_adv.asp 